УДК 347.73

DOI https://doi.org/10.32837/yuv.v0i4.2234

\author{
Д. Мазуренко, \\ аспірантка кафедри фінансового права \\ Національного юридичного університету \\ імені Ярослава Мудрого
}

\title{
РЕАЛІЗАЦІЯ РОЗСУДУ В ПОДАТКОВОМУ ПРАВІ
}

Вступ. Все більше вітчизняних і закордонних науковців звертаються до проблеми розсуду у праві. Питання про розсуд у праві є досить складним i дискусійним через багатогранність поняття та відсутність єдиного підходу до розуміння категорії «розсуд». Нині актуальним є питання щодо доцільності застосування розсуду в податково-правовому регулюванні. Чи можливо взагалі у сфері правового регулювання, в якій переважає імперативний метод, діяти, базуючись на власному розсуді?

Це дослідження є неможливим без характеристики та врахування результатів наукових розробок таких представників загальної теорії держави і права, як С.С. Алексєєв, В. А. Сапун, Л. О. Морозова, Н. Н. Крестовська та іноземних правознавців Р. Дворкіна, А. Барака. Окремі аспекти розсуду вирішувалися в межах галузевих досліджень М. Б. Рісного, T. С. Мартьянової, О. А. Папкової, I. I. Полякова, Ю. А. Тихомирова; у сфері податкового права розсуд розглядався у працях М. П. Кучерявенко, Н. О. Ханової, І. Л. Желтобрюх.

Виклад основного матеріалу. Мета роботи - дослідження проявів розсуду в податковому праві та розмежування поняття «розсуд» із суміжними поняттями. Відповідно до поставленої мети пропонується вирішення таких завдань: визначити основні сфери реалізації розсуду; охарактеризувати спільні та відмінні риси понять «розсуд» і «дискреція»; відмежувати поняття «дискреції від поняття «дискреційні повноваження».
Відносини між публічними і приватними суб'єктами мають конфліктний характер, зокрема платник податку бажає збільшити дохід та мінімізувати суми відрахувань до бюджетів у вигляді податків і зборів, тоді як податкові органи здійснюють контроль за дотриманням податкового законодавства та забезпечують повне і своєчасне надходження грошових коштів до бюджетів. Саме тому зрозумілим є прагнення законодавця забезпечити баланс інтересів i врегулювати податкові відносини так, щоб уникнути конфліктності. Але в сучасних умовах, незважаючи на імперативність податково-правових відносин, трапляються випадки прояву диспозитивності, коли закон надає можливість суб'єкту діяти на власний розсуд. Наприклад, Конституція України встановлює обов'язок кожної людини сплачувати податки і збори в порядку та розмірах, встановлених законом. Для виконання цього обов'язку платник податку може самостійно обрати загальну або спрощену систему оподаткування.

Для того, щоб зрозуміти, яким чином розсуд проявляється в податково-правовому регулюванні, необхідно звернути увагу на об'єктивні та суб'єктивні фактори розсуду. Об'єктивні фактори поділяються на «планові», коли законодавець спеціально створює певний простір, у рамках якого суб'єкт може діяти самостійно, та «вимушені», коли законодавець допустив прогалину під час формулювання правових норм. Суб'єктивні фактори розсуду 
визначаються індивідуальними властивостями суб'єкта (рівень індивідуальної правосвідомості і правової культури суб'єкта правореалізаціі) та формуються під впливом навколишнього середовища (сформований під впливом соціального середовища вид правової поведінки).

Розсуд існує на двох рівнях: законодавчому та правозастосовному. Законодавчий орган ухвалює закон, в якому встановлено перелік загальнодержавних та місцевих податків і зборів, надаючи повноваження органам місцевого самоврядування на введення таких податків і зборів на відповідній території. Місцеві податки i збори поділяються на обов'язкові для встановлення місцевими радами, зокрема єдиний податок i податок на майно (в частині транспортного податку та плати за землю, крім земельного податку за лісові землі), та на ті, за якими місцеві ради в межах повноважень, закріплених ПК України, вирішують питання про встановлення: податку на майно (в частині податку на нерухоме майно, відмінне від земельної ділянки) та збору за місця для паркування транспортних засобів, туристичного збору і земельного податку за лісові землі. Тобто не всі місцеві податки і збори є обов'язковими до запровадження місцевими радами. Місцеві ради мають певну самостійність, а саме повноваження щодо: встановлення місцевих податків і зборів, передбачених ПК України; прийняття рішення про встановлення місцевих податків і зборів, про зміну розміру їхніх ставок, об'єкта оподаткування, порядку справляння та надання пільг.

Незважаючи на те, що в податковому праві розсуд існує на законодавчому рівні, основною сферою здійснення розсуду було й залишається правозастосування. Для дослідження «розсуду» на рівні податкового правозастосування треба з'ясувати, що таке правозастосування та як воно співвідноситься 3 реалізацією права.
Реалізація права - це остання стадія правового регулювання, за якої право втілюється в життя, тобто це процес реального втілення змісту юридичних норм у фактичній поведінці суб'єктів [1, с. 254,2 , с. 249]. За характером дій суб'єктів і ступенем їхньої активності зазвичай виділяють три форми безпосередньої реалізації права, під час яких юридичні норми втілюються в життя діями самих суб'єктів права: дотримання, виконання, використання.

Дотримання норм права. Ця форма реалізації права наявна, коли суб'єкти утримуються від здійснення дій, заборонених правом. Наприклад, згідно з п. 44.1 ст. 44 ПК України платникам податків забороняється формування показників податкової звітності, митних декларацій на підставі відомостей, не підтверджених документами, визначеними абзацом першим цього пункту. Відповідно до п. 85.1 ст. 85 ПК України будь-яким посадовим (службовим) особам контролюючих органів забороняється витребування документів від платника податків у випадках, не передбачених ПК України.

Виконання норм права відбувається, коли суб'єкти здійснюють покладені на них юридичні обов'язки. Наприклад, платник податків зобов'язаний надати посадовим (службовим) особам контролюючих органів у повному обсязі всі документи, що належать або пов'язані з предметом перевірки. Такий обов'язок виникає у платника податків після початку перевірки відповідно до п. 85.2. ст. 85 ПК України. Для контролюючого органу існує обов'язок доведення того, що будь-яке нарахування, здійснене контролюючим органом у випадках, визначених ПК України, або будь-яке інше рішення контролюючого органу є правомірним під час процедури адміністративного оскарження згідно з п. 56.4. ст. 56 ПК України.

Використання норм права - це форма реалізації права, коли суб'єкти 
на свій розсуд використовують надані їм права. Відповідальність за невикористання своїх прав законодавством не передбачена, але це відноситься тільки до фізичних осіб, державних органів і посадових осіб, невиконання якими своїх повноважень є правопорушенням. Згідно з положеннями п. 17.1.2. ст. 17 ПК України, платник податків має право представляти свої інтереси в контролюючих органах самостійно, через податкового агента або уповноваженого представника. Відповідно до п. 20.1.3 ст. 20 ПК України контролюючі органи мають право отримувати безоплатно від державних органів, органів місцевого самоврядування, підприємств, установ та організацій усіх форм власності та їхніх посадових осіб, зокрема від органів, які забезпечують ведення відповідних державних реєстрів (кадастрів), інформаціі,, документів і матеріалів [3].

У формах безпосередньої реалізації права реалізується багато норм, але існують випадки, коли для їх реалізації потрібне втручання компетентних органів, наділених державно-владними повноваженнями. $\mathrm{y}$ цьому випадку йдеться про особливу форму реалізаціі права - правозастосування. Правозастосування - це владна діяльність державних органів і посадових осіб, яка забезпечує реалізацію права шляхом винесення індивідуального юридичного рішення щодо конкретних суб'єктів із метою виникнення, зміни або припинення правовідносин на основі чинних норм [4, с. 254].

Науковці по-різному оцінюють співвідношення понять «реалізація права» i «застосування права». Л. О. Морозова вирізняє правозастосування як четверту форму реалізації права [2, с. 250]. Зі свого боку С. С. Алексєєв [4, с. 254], H. Н. Крестовська [5], В. А. Сапун [1] розглядають правозастосування як особливу форму реалізаціі права. Це пояснюється тим, що існує значна відмінність між правозастосуванням і безпосередньою реалізацією права. Суб’єкт безпосередньої реалізації права самостійно визначає свою поведінку згідно з правовими приписами, а суб'єкт правозастосування упорядковує не свою поведінку, а поведінку сторонніх суб'єктів. Отже, правозастосування - це особлива форма реалізації права, яку здійснюють тільки суб'єкти владних повноважень, тобто контролюючий орган. У свою чергу безпосередня реалізація здійснюється як контролюючим органом, так і платником податків.

Проблема розсуду під час безпосередньої реалізації права не досить досліджена в юридичній науці, чому існує декілька причин. По-перше, розсуд переважно досліджувався науковцями як явище негативне через порушення законодавства 3 боку органів державної влади. По-друге, для держави важливіше домогтися від зобов'язаних осіб точного дотримання правових приписів, ніж створити можливість активного користування правами та виконання обов'язків, однак у законі закріплюється формулювання «діяти на власний розсуд». Хоча основною сферою реалізації розсуду є податкове правозастосування, актуально буде проаналізувати «розсуд» 3 боку інших форм реалізаціі права (дотримання, виконання, використання), оскільки певні можливості вибору реалізації права чи обов'язку на свій розсуд притаманні й зобов'язаним особам [6, с. 38]. Наприклад, коли платник податків у межах презумпції правовірності рішень платника податків обирає один із декількох альтернативних алгоритмів поведінки, він фактично реалізує розсуд, тобто зобов'язаній стороні податкових правовідносин надається право на власний розсуд застосовувати ту чи іншу норму.

У сучасній правовій науці широковживаним є визначення ізраїльського науковця А. Барака, який вказує, що «розсуд» - це повноваження суб'єкта 
для вибору між двома та більше альтернативами, кожна з яких $€$ законною [7, с. 13]. Здійснення розсуду ніколи не буває абсолютним. Навіть якщо право прямо встановлює, що розсуд є абсолютним, це тлумачиться як вимога від носія влади діяти відповідно до певних процедур, щоб досягти цілей законодавства, 3 яких зароджується влада. Розсуд органів адміністративної влади завжди прив'язується до обов'язків, зокрема до завдань, заради яких такий орган має діяти на власний розсуд. Свобода вибору ніколи не буде необмеженою, оскільки абсолютна свобода означає початок іï кінця [7, с. 28-29]. Хоча науковець розглядає правовий феномен стосовно сфери суддівського розсуду, але запропоновану дефініцію можна поширювати на будь-яку державно-владну діяльність.

Американський науковець Р. Дворкін у праці «Серйозний погляд на права» використовує словосполучення «особа вирішує на власний розсуд» у таких значеннях:

1) діяльність особи визначається стандартами (правовими нормами), які розумна особа може інтерпретувати по-різному. На підставі правових норм особа виробила власне судження, яке застосує для вирішення;

2) рішення особи $є$ остаточним, оскільки вища інстанція не може переглянути або скасувати це рішення;

3) на особу покладають обов'язки, визначені стандартами (правовими нормами), які фактично не мають на меті нав'язати певне рішення [8, c. 105].

Перший та другий варіант «розсуду» науковець називає слабкими для того, щоб відрізнити їх від більш сильного значення. У сильному розумінні «рішення на власний розсуд» - це рішення суб'єкта, не пов'язане 3 нормами, визначеними державою.

У своїй праці О. А. Папкова розглядає суддівський розсуд як різновид правозастосувального розсуду. Суддівський розсуд - це врегульований нормами права і здійснюваний у процесуальні формі специфічний вид правозастосовної діяльності суду, сутність якого полягає у виборі варіанта рішення правового питання, який має загальні та спеціальні межі [9, с. 39].

Н. А. Бааджи надає таке визначення адміністративного розсуду: адміністративний розсуд - це елемент юридичної діяльності суб'єкта публічної адміністрації, органу чи посадової особи, який характеризується певною свободою у правовому вирішенні того чи іншого питання, яка надається йому для прийняття раціонального, мотивованого й обгрунтованого рішення у справі в межах, визначених нормами права [10, с. 11].

На думку $M$. Б. Рісного та Т. С. Мартьянової, «правозастосувальний розсуд» - це владне повноваження правозастосувального суб'єкта обирати один із декількох дозволених ним варіантів рішення в межах своєї компетенції шляхом ухвалення правомірного рішення, враховуючи принципи права, положення чинного законодавства, конкретні обставини справи, а також вимоги доцільності, добросовісності, справедливості та основ моралі [11, с. 9; 12, с. 12-13].

Досить цікавим вбачається погляд на проблему розсуду у праві I. I. Полякова, який вважає, що «розсуд» належить до суб'єктивної (психологічної) сторони правомірної поведінки. Тобто розсуд - це вибір суб'єктом визначеної мети і способів пї досягнення або можливість виражати власну волю та приймати рішення незалежно від волі інших осіб [13, с. 234-238]. Суб'єктивний розсуд необхідно відрізняти від правозастосувального розсуду. По-перше, за суб'єктивного розсуду платник податку наділений суб'єктивним правом для задоволення власного інтересу на відміну від правозостосувального розсуду, коли контролюючий орган не має власного інтересу під час правозастосування, 
оскільки державні органи здійснюють покладені на них повноваження в рамках посадових обов'язків, виступаючи за такої умови від імені суспільства та держави. По-друге, істотною відмінністю є підхід до визначення міри свободи розсуду вищезазначених суб’єктів. У першому випадку розсуд суб'єкта (платника податку) підкоряється правилу: «дозволено все, що не заборонене законом», а в другому (для контролюючого органу) - «дозволено тільки те, що безпосередньо вказане в законі». Тому цілком очевидно, що межі розсуду в першому випадку набагато ширші, ніж у другому.

Отже, вищезазначені визначення розсуду доцільно розмежувати залежно від суб'єкта застосування на приватний і публічний. У своїх працях М. Б. Рісний та Т. С. Мартьянова розглядали публічний (правозастосувальний) розсуд, який здійснюється органами державної влади та посадовими особами. Суддівський розсуд (Р. Дворкін, А. Барак, О. А. Папкова) та адміністративний розсуд (Н. А. Бааджи) це види правозастосувального розсуду. Приватний розсуд (суб'єктивний розсуд) розглядає I. I. Поляков, коли суб'єктом розсуду є платник податку. Аналіз наукових поглядів дозволяє констатувати, що більшість науковців вважають обгрунтованим таке розуміння розсуду, як можливість суб'єкта обирати між двома чи більше варіантами рішення, дозволеними правом. Отже, необхідно виділити дві основні ознаки розсуду: 1) наявність декількох, як мінімум двох, варіантів рішення; 2) вибір повинен здійснюватися тільки між наявними законними варіантами.

Дуже близьким за значенням поняттю «розсуд» $€$ термін «дискреція» («дискреційні повноваження»). Словник української мови визначає дискрецію як вирішення посадовою особою або державним органом будь-якого питання на власний розсуд [14]. В юридичній енциклопедії Ю. С. Шемшученко надається визна- чення поняття «дискреційна влада», яке походить від французького слова discretionnaire, що означає залежність від власного розсуду. Дискреційна влада - це спосіб реалізації публічної (тобто з боку держави і місцевого самоврядування) влади, за яким відповідний суб'єкт влади (орган чи посада, особа) застосовує надані йому в межах закону повноваження на власний розсуд, без необхідності узгодження у будь-якій формі своїх дій 3 іншими суб'єктами [15]. Проаналізувавши судову практику, можна стверджувати, що суди неодноразово посилаються на Рекомендацію № $\mathrm{P}(80) 2$ Комітету Міністрів Ради Європи від 11.03.1980 (далі - Рекомендації № Р(80)2). Наприклад, у постанові Верховного Суду від 11.09.2019 у справі № 819/570/18 суд сформував позицію щодо поняття дискреційних повноважень на підставі Рекомендації № Р(80)2, відповідно до якої дискреційні повноваження - це повноваження, які адміністративний орган, приймаючи рішення, може здійснювати з певною свободою розсуду (тобто коли такий орган може обирати з кількох юридично допустимих рішень те, яке він вважає найкращим за цих обставин) [16]. Зауважимо, що текст Рекомендації № R(80)2 відсутній на офіційному вебпорталі парламенту України. Рекомендація № $\mathrm{R}(80) 2$ не є частиною національного законодавства; вона має рекомендаційний характер, однак суди на практиці найчастіше здійснюють посилання на Рекомендацію № $\mathrm{R}(80) 2$. Подібне визначення «дискреційних повноважень» міститься в національному законодавстві, а саме в чинній Методології проведення антикорупційної експертизи, затвердженій Наказом Міністерства юстиції України від 24.04.2017 № 1395/5. Згідно з п. 1.6 дискреційні повноваження визначаються як сукупність прав та обов'язків органів державної влади i місцевого самоврядування осіб, уповноважених на виконання 
функцій держави або місцевого самоврядування, які надають можливість на власний розсуд визначати повністю або частково вид і зміст управлінського рішення, що приймається, або можливість вибору на власний розсуд одного з декількох варіантів управлінських рішень, передбачених нормативно-правовим актом і проєктом нормативно-правового акта [17].

Отже, нині законодавчі дефініції понять «розсуд» та «дискреція» відсутні, хоча ці терміні неодноразово зустрічаються в численних законах та підзаконних нормативно-правових актах. Визначення поняття «дискреційні повноваження», наведені вище, часто використовуються в рішеннях суддів та в інших сферах права. Вищезазначене свідчить про те, що категорія «розсуд» виступає родовим поняттям стосовно поняття «дискреція». Розсуд характеризується диспозитивністю та універсально застосовується в податковому праві як до владного суб'єкта, так і до зобов'язаного учасника податкових відносин. Що стосується терміна «дискреція», то він застосовуватиметься виключно для характеристики статусу владних суб'єктів.

Проте слід зазначити, що категорії «дискреція» та «дискреційні повноваження» не є тотожними. Щоб зрозуміти значення терміна «дискреційні повноваження», треба позначити, що включає в себе термін «повноваження». В юридичній енциклопедії поняття «повноваження» трактується як сукупність прав та обов'язків державних органів і громадських організацій, а також посадових та інших осіб, закріплених за ними у встановленому законодавством порядку задля здійснення покладених на них функцій [15]. Отже, термін «повноваження» розглядається як єдність прав та обов'язків.

Як відомо, дискреція - це право суб'єкта, тому постає питання: як дискреційні повноваження можуть бути обов'язковими для контролю- ючого органу? Стосовно цього існує низка поглядів, на які необхідно звернути увагу. Зокрема Ю. О. Тихомиров вважає, що права надаються органам державної влади для їх подальшої обов'язкової реалізації. В єдності прав та обов'язків і виражається специфіка такої категорії, як «повноваження». Публічна сфера припускає поєднання прав та обов'язків у формулу повноваження як правообов'язки, які не можна не реалізувати в публічних інтересах [18, с. 67]. Натомість Н. О. Ханова поділяє права контролюючих органів на обов'язкові для іхньої реалізації і ті, що реалізуються за розсудом. Наприклад, у вказаних органів є право проводити перевірки платників податків. Водночас за наявності хоча б однієї із підстав, що містяться у п. 78.1 ст. 78 ПК України, вказане право трансформується у «право-обов'язок» здійснювати документальну позапланову перевірку. Науковець вважає, що більш доцільно говорити про категорію «дискреційні права», а не про категорію «дискреційні повноваження» або ж окреслювати умовність використання поняття «повноваження», хоча наведене вище не заперечує можливість оперування категорією «дискреційні повноваження» як усталеним поняттям [19, с. 12]. Вважаємо, що права контролюючих органів спрямовані на виконання завдань і функцій цього органу, тому є обов'язковими для реалізації. Отже, формулювання повноважень як термінологічної сполуки «право-обов'язок» $є$ актуальним і доцільним під час визначення терміну «дискреційні повноваження».

Висновок. Проаналізувавши вищезазначене, слід зробити висновок, що термін "розсуд» втілюється у сфері реалізації права і грунтується на вимогах правових норм. Традиційно в теорії права розрізняють три основні форми реалізації права: використання прав, виконання обов'язків і дотримання заборон. Особливою формою реалізації права 
є правозастосування. Проте слід зазначити, що правозастосування характерне лише для владних суб'єктів, як i вживання терміну «дискреція». 3 урахуванням сучасних наукових підходів до розуміння правозастосувального розсуду потребують подальших досліджень інші сфери реалізації розсуду в податковому праві, а саме реалізація розсуду суб'єктів, які мають можливість вибору варіанта поведінки задля задоволення власного інтересу.

На основі проведеного аналізу можна виокремити спільні та відмінні риси термінів «розсуд» $\mathrm{i}$ «дискреція».

Відмінними рисами є такі:

1) розсуд має ширше значення, ніж дискреція, тому що розсуд виступає родовою категорією;

2) розсуд застосовується до всіх суб'єктів податкового права, тоді як дискреція - лише до владного суб'єкта;

3) суб'єктивний розсуд зобов'язаного суб'єкта спрямований на задоволення власного інтересу. Так само дискреція владного суб'єкта не має власного інтересу і здійснюється в інтересах держави;

4) розсуд - це право владного та зобов'язаного суб'єкта, тоді як дискреційні повноваження (право-обов'язок) - владного суб'єкта. Тобто зобов'язані особи можуть і не здійснювати надані їм законом права, тоді як для суб'єктів владних повноважень права є їхнім обов'язком, а не суб'єктивним правом.

Спільними рисами є такі:

1) розсуд і дискреція характеризуються диспозитивністю;

2) розсуд і дискреція - це свобода дій, обмежених об'єктивним правом (певними межами);

3) розсуд і дискреція мають два або більше варіантів поведінки, кожен з яких є законним.

У статті проаналізовано прояв диспозитивності в податковому праві, оскільки закон надає суб'єкту право обирати на власний розсуд. Авторкою виділено об'єктивні та суб'єктивні фактори розсуду.

У статті акцентовано увагу на тому, що переважно дослідження категоріі «розсуд» зводиться до вивчення правозастосовного розсуду в загальнотеоретичному ракурсі, а також адміністративного та судового розсуду, які $\epsilon$ особливими різновидами правозастосовного розсуду, або з погляду на галузеві особливості, зокрема в податковому праві. Подібні підходи звужують категорію розсуду та виключають з неї розсуд інших суб'єктів права, які мають можливість вибору варіантів поведінки.

Авторкою розмежовано такі поняття, як «розсуд» та «дискреція», та указано, що термін «розсуд» має ширше значення порівняно 3 терміном «дискреція». Розсуд застосовується для всіх суб'єктів податкового права, тоді як дискреція - тільки для владних суб’єктів. За реалізаціі розсуду зобов'язана особа наділена правом задоволення власного інтересу на відміну від владної сторони правовідносин, яка не має власного інтересу, а реалізуе надані їи повнованення в інтересах суспільства та держави.

Крім того, у статті детально проаналізовано відмежування понять «дискреція» та «дискреційні повноваження». Дискреційні повноваження розглядаються як єдність прав та обов'язків державних органів, а термін «дискреція» означає право суб'єкта обирати один із декількох наявних варіантів. Досліджено погляди науковизів із изього питання, які вказують, що повноваження розглядаються як термінологічна сполука «право-обов'язок».

Наголошено на тому, щзо суди неодноразово використовують у своїх рішеннях визначення «дискреційні повноваження», яке міститься в Рекомендащії Коміmemy Miнicmpiв Ради Європи ma 
має рекомендаційний характер для українського законодавства. Авторкою вказано на необхідність закріплення на законодавчому рівні термінів «розсуд» та «дискреція».

Ключові слова: розсуд, дискреція, дискреційні повноваження, правозастосування, реалізація розсуду.

\section{Mazurenko D. Judgment realisation in tax law}

The article analyzes the manifestation of dispositiveness in the tax law, as the law gives the subject the right to choose at its judgement. The author distinguishes between objective and subjective factors of judgement.

The article emphasizes that prevalently the study of the judgement category is resolve itself to the study of law enforcement judgement in a general theoretical perspective, administration and judicial judgement, which are a special kinds of law enforcement judgement, or in terms of sectoral features, including the tax law. Such approaches narrow the judgement category and exclude from it the judgement of other law subjects who have the opportunity to choose options for behavior.

The author distinguishes between such concepts as "judgement" and "discretion". In this regard, it is pointed out that the term "judgement" has a broader meaning than "discretion". The judgement applies to all subjects of the tax law, in turn discretion applies only to the subjects of authority. In exercising the judgement, the obligated person is endowed with the right to satisfy their own interest, in contrast to the authoritative party of legal relations, which has no self-interest, but exercises the powers granted to it in the interests of society and the state.

In addition, the article analyzes in detail the distinction between "discretion" and "discretionary powers". Discretionary powers are seen as the unity of the rights and responsibilities of public authorities, and the term "discretion" means the right of a subject to choose one of several options. The views of scholars on this issue have been examined, indicating that powers are seen as a term of legal responsibilities.

It is emphasized that courts have repeatedly used in their decisions the definition of "discretionary powers" contained in the Recommendation of the Committee of Ministers of the Council of Europe, which is of a recommendatory nature for Ukrainian legislation. The author points out the need to enshrine at the legislative level the terms "judgement" and "discretion".

Key words: judgement, discretion, discretionary powers, law enforcement, realization of discretion.

\section{Лiтература}

1. Основи теории государства и права: учеб. пособие. Ред. В. А. Сапун. Санкт-Петербург: Изд-во СПбГЭУ, 2016. 304 c

2. Морозова Л. А. Теория государства и права: учебник. 4-е изд., перераб. и доп. Москва: Российккое юридическое образование, 2010. 384 c.

3. Податковий кодекс Украӥни: Закон України від 02.12.2010 p. № 2755-VI. Відомості Верховної Ради України. 2011, № 13-14, № 15-16, № 17, cm. 112 . URL: https://zakon.rada.gov.ua/laws / show/2755-17/ed20180101 (даma звернення: 18.08.2021).

4. Алексеев С. С. Теория права. Изд. 2-е, перераб. и доп. Москва: БЕК, 1995. 320 c.

5. Крестовська Н. М., Матвеева Л. Г. теорія держави і права: Елементарний курс. Видання друге. Харків : ТОВ «Одіссей», 2008. 432 c.

6. Кучерявенко М. П. Особливості розсуду в податково-правовому регулюванні. ScienceRise : Juridical Science. 2017. № 1. C. 37-41.

7. Барак А. Судейское усмотрение. пер. с англ. Ч. 1. Москва : Издательство НОРМА, 1999. 376 c.

8. Дворкин Р. О правах всерьез : моногр / пер. с англ.; ред. Л. Б. Макеева. 
Москва : Рос. полит. энциик. (РОССПЭН), 2004. 392 c.

9. Папкова О. А. Усмотрение суда. Москва: Cmamym, 2005. 413 c.

10. Бааджи Н. А. Адміністративний розсуд в діяльності органів публічної адміністрації) : автореф. дис. ... канд. юрид. наук: 12.00.07 / Одес. держ. ун-т внутр. справ. Одеса, 2020. 20 c.

11. Рісний М. Б. Правозастосувальний розсуд (загальнотеоретичні аспекти) : автореф. дис. ... канд. юрид. наук: 12.00.01/ Львів. наи. ун-m ім. І.Франка. Львів, 2006. 16 с.

12. Мартьянова T. С. Розсуд суб'єктів правозастосовної діяльності : автореф. Әис. ... канд. юрид. наук: 12.00.01 / Наи. ун-m «Львів. політехніка». Львів, 2013. 23 c.

13. Поляков I. I. Розсуд у праві: поняття, ознаки і види. Актуальні проблеми політики : зб. наук. пр. МОН України, ОНЮА. Одеса : Фенікс, 2009. Вип. 38. C. 233-239.

14. Тлумачний словник української мови: у 20-ти томах: електронна версія видання / Наи. акад. наук України, Укр. мовно-інформ. фонд; гол. ред. В. М. Русанівський ; науковий керівник проекту
B. A. Широков, 2010. URL: https:// slovnyk.me / dict / newsum / дucкреuія (дата звернення: 18.08.2021).

15. Юридична енциклопедія: в $6 \mathrm{~m}$. / редкол.: Ю. С. Шемиученко (голова редкол.) та ін. Київ: Укр. енцикл., 1998. URL: https: / / leksika.com.ua (дата звернення: 18.08.2021).

16. Постанова Касаиійного адміністративного суду у складі Верховного Суду від 09.11.2018 р., судова справа № 263/15749/16-a. URL: https:// reyestr.court.gov.ua/Review / 77799030 (дата звернення: 18.08.2021).

17. Методологія проведення антикорупційної експертизи: затв. наказом М-ва юстииї України від 24.04.2017 № 1395/5. URL: https: / / zakon.rada.gov.ua/laws/ show/v1395323-17\#n15 (дата звернення: 18.08.2021).

18. Тихомиров Ю. А. Публичное право: учеб. Москва: Изд-во БЕК, 1995. 496 с.

19. Ханова Н. О. Дискреційні повноваження контролюючих органів у сфері оподаткування в Україні : автореф. дис. ... канд. юрид. наук: 12.00 .07 / Університет митної справи та фінансів. Дніпро, 2019. 22 c. 